\author{
エンジン同時3点点火用高輝度Nd:YAG/Cr:YAG \\ セラミックマイクロレーザー \\ 常包 正樹 ${ }^{1}$, ニコライ・パベル ${ }^{1,2}$, 平等 拓範 ${ }^{1}$ \\ ${ }^{1}$ 自然科学研究機構 分子科学研究所 分子制御レーザー開発研究センター（†444-8585 愛知県岡崎市明大寺町字西郷中 38) \\ ${ }^{2}$ レーザー・プラズマ・放射物理国立研究所 固体量子エレクトロニクス研究室 \\ (Atomistilor Street 409, Magurele, Bucharest R-077125, Romania)
}

\title{
Simultaneously 3-Point Ignitable, Nd:YAG/Cr:YAG Ceramic Micro-Lasers
}

\author{
Masaki TSUNEKANE, ${ }^{1}$ Nicolaie PAVEL,${ }^{1,2}$ and Takunori TAIRA ${ }^{1}$ \\ ${ }^{1}$ National Institutes of Natural Sciences, Institute for Molecular Science, Laser Research Center for Molecular Science \\ 38 Nishigo-Naka, Myodaiji, Okazaki, Aichi 444-8585, Japan \\ ${ }^{2}$ National Institute for Lasers, Plasma and Radiation Physics Laboratory of Solid-State Quantum Electronics \\ Atomistilor Street 409, Magurele, Bucharest R-077125, Romania
}

(Received July 30, 2012)

\begin{abstract}
An actual spark plug-sized laser with ignitable, three beam output was successfully demonstrated for simultaneous multi-point ignition of automobile engines. The closed parallel laser array consisted of a single active source of a composite, 10-mm long all-ceramics Nd:YAG/Cr:YAG monolithic laser cavity and three independent pump and focus optics lines. Laser pulses with energy of $3.2 \mathrm{~mJ}$ and a duration of $500 \mathrm{ps}$ ( $>6 \mathrm{MW}$ peak power) were obtained from each laser at $20-\mathrm{Hz}$ repetitions.
\end{abstract}

Key Words: Diode pumped solid-state laser, Passively Q-switched laser, High brightness, Laser ignition, Breakdown

\section{1. はじめに}

自動車用エンジンを代表とする内燃機関の高効率化を 実現できる新しい点火方式として，高輝度固体レーザー を用いたレーザー点火の研究を進めている。我々は2006 年より科学技術振興機構 (JST)の地域イノベーション創 出総合支援事業「光波反応制御内燃機関をめざしたマイ クロレーザーの研究開発」に於いて, 平等の提唱する 「ジャイアントマイクロフォトニクス」の設計思想を基に LD励起のNd:YAG/Cr:YAG受動Qスイッチレーザーの小 型化, 高輝度化最適設計を行い, 点火が可能な高輝度 レーザーをプラグサイズまで小型することに成功し た ${ }^{1)}$.さらに2008年からのJST産学官共同シーズイノ ベーション事業「車載型マイクロレーザ点火エンジンの 研究」では実用化と高性能化を進め, 共同研究を行って いる日本自動車部品総合研究所において, 最終目標で あった世界初となる市販車両のガソリンエンジンにレー ザープラグを搭載しての走行実験にも成功している。本 稿ではシーズイノベーション事業の中で高性能化の一環 として行った, 内燃機関のさらなる高効率化を可能にす る次世代の同時多点点火レーザーモジュールの開発研究 の結果について報告する.
2. レーザーによる同時多点点火の利点

現在普及しているスパークプラグによる電気火花点火 (Fig. 1（a））では，電極による冷却効果により火炎核形 成時の燃焼エネルギーの消失が50\%以上と大きい。ま た，電極の温度上昇による溶解から燃焼室中央で点火す ることは困難であり, さらに電極が燃焼室内部に突き出 た異物として，シリンダー内の火炎伝搬を妨げる障害物 となっている。このためスパークプラグを用いて, シリ ンダー内で理想的な高効率燃焼状態を作り出すことには 限界がある。さらに燃料の利用効率低下と不完全燃焼が 原因となって発生する一酸化炭素や窒素酸化物の排出量 を低減することも困難である。

これに対しレーザー光による光電離点火 ${ }^{2,3)}$ は, 電極 が不要であるため空間的に自由度の高い光の特性を利用 して燃焼室中央で点火することが可能であり，火炎が冷 たい燃焼室壁から受ける損失が小さく, 高効率な燃焼を 促進できる。またレーザー点火の大きな特長として，プ ラズマ生成メカニズムの違いからスパークプラグでは点 火が難しい高圧の燃料ガスに対しても点火が可能である 点も上げられる。燃焼効率の改善から, 高圧縮化は新型 エンジン開発の必然的な流れであり, レーザー点火の重 
要性はますます高まるものと予測される。また車用では ないが，既に高圧縮下で稼働しているコジェネレーショ ン (発電)用のガスエンジンでは, 点火プラグの電極の摩 耗が速く頻繁な交換が必要であることから，レーザー点 火実用化に寄せる期待が高い。しかしながらこれまでス パークプラグと同じエンジンの実働環境でテストできる レーザー光源がなかったため，レーザー点火による燃費 改善の割合については世界でも明確な報告はなかった。

これについては我々が推進した先のJSTプロジェクトの 中で, 昨年, 日本自動車部品総合研究所がオールレー ザー点火のガソリンエンジンを搭載した実走行可能な車 両の試作に世界で初めて成功し, その評価結果として初 めて4\%という燃費改善の実測值を得ることができた。 この数值はあまり大きいという印象はないかもしれない が, 日本国内での全石油消費(LPガス, 原油含む)に占 める自動車用燃料の割合は約 $40 \%$ と最も高く, そのうち の4\%にあたる石油(原油)量は莫大で, 一般家電の省工 ネ効果による原油削減量とは桁違いに大きく, 効果は絶 大である。なお，この実車走行実験は，現行市販車両の スパークプラグをレーザーに置き換えただけの初期的な ものであり，レーザーの点火位置の最適化や燃料の高圧 縮化などはまだ行っていないため, 今後さらなる燃費の 改善が期待できる.

さらに，レーザー点火においては，電極がない自由度 をさらに活かし, Fig. 1（b）の示す同時多点点火の有効 性も古くから研究されてきた ${ }^{4,5)}$. さらなる燃焼時間の

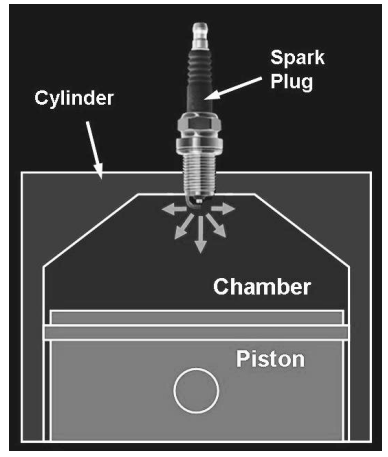

(a)

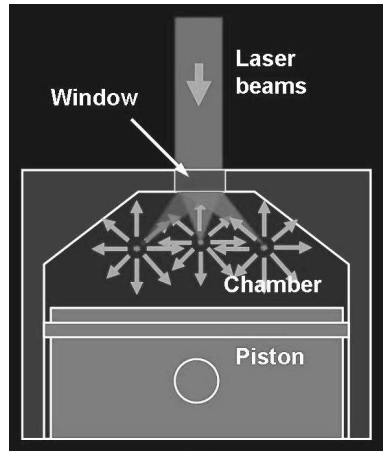

(b)
Fig. 1 Configurations of ignitions using a spark plug (a) and a laser (b). (b) shows multipoint ignition.
短縮と燃焼効率の大幅な改善が可能である，特に1点で は燃焼に時間のかかる燃焼室口径の大きなエンジンへの 効果が高い．燃焼効率の改善は単に現行のエンジンの出 力向上だけではなく，燃費の低減，より希薄な燃料ガス への点火の可能性を意味している.

\section{3. 同時3点点火用高輝度マイクロレーザーの試作}

\section{1 同時3点点火レーザーの構成}

Fig. 2 (a) (b) に, 検討した多点 (3点) 点火レーザーの 構成概念の例を示す。（a）は一つのレーザーからの出力 をビームスプリッター等で分岐する方式で，（b）は単純 に3つの独立したレーザーをアレイ状に近接させたもの である。（a）は部品点数の少なさから最もシンプルで小 型化も容易だが，点火のためには1ビーム当たり MWを 超える高い光エネルギーが必要であるため, レーザー発 振器には1つのレーザーでそのビーム倍の光エネルギー を発生させる必要がある。しかし実際にはビーム内で光 強度がコーティングのダメージしきい值を超えてしまう 可能性が高く, 信頼性上大きな問題となる。 またビーム 面積を広げ光強度を下げて出力を上げようとしても，プ ラグサイズに収まる $10 \mathrm{~mm}$ 程度の短いマイクロレーザー 共振器ではレーザービームの品質が急激に低下するた め, 逆に集光時の光強度が下がり点火できなくなる。こ の点, (b)の構成は部品点数が3倍に増えるものの, ダ メージなど信頼性の面では不安が少なく, これまでに1 点点火で確立しているレーザー設計が適用可能である. さらにこの図のように，一体化した受動Qスイッチレー ザー共振器を大口径化し，その異なる3力所を端面励起 すれば，同じ共振器から発生する3つのレーザービーム は必ず平行になるため, その後の点火光学系のレンズア ライメントが容易になる。そこで今回 (b)の構成にて多 点レーザーの研究試作を進めた。なお今回, 現行のプラ グサイズのモジュールに収めることが可能なビームの数 として3を選択しだ．

\section{2 共振器一体型受動QスイッチNd:YAG/Cr:YAGセ ラミックの発振特性}

今回の同時多点点火レーザー発振実験では, 受動 $Q$ ス イッチレーザーのゲイン媒質Nd:YAGおよび光スイッチ 素子として可飽和吸収体のCr:YAGに，新たにセラミッ

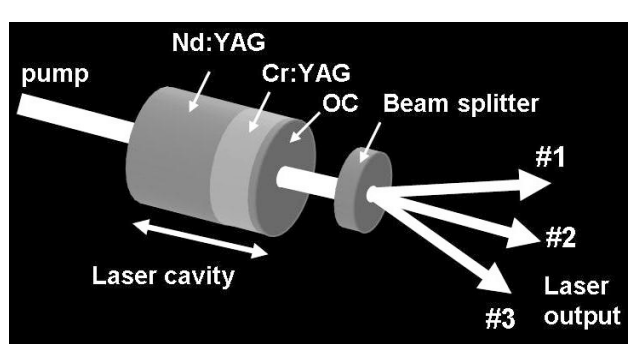

(a)

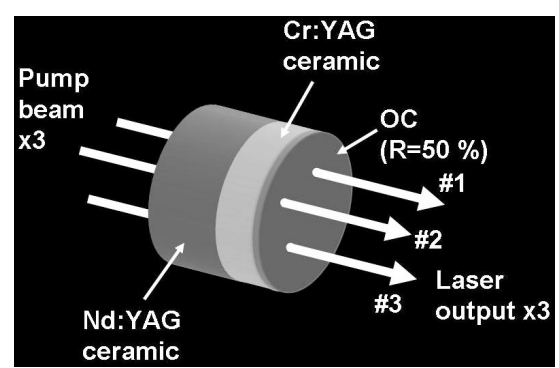

(b)

Fig. 2 Schematics of three beam laser systems. (a) one laser oscillation beam, and (b) three beam laser array. 
ク材料を採用した。近年国産の独自技術として実用化さ れた透光性レーザーセラミック材料 ${ }^{7,8)}$ は単結晶に比べ 多くの利点を有すが，ここで我々が注目したのは，大口 径の材料が高均一に作成可能であること, $\mathrm{Nd}: \mathrm{YAG}$ と Cr:YAGを接着剂を使用せず，製造の過程で強固に一体 化したコンポジット構造が容易に製作できるという点で ある。加えてNd:YAGセラミックスの特長として, $\mathrm{Nd}$ の 添加濃度を1.1at.\%以上に上げても濃度消光によるレー ザー特性の劣化が単結晶にくらべ小さいことが挙げられ る。 Ndを高濃度添加すれば短いレーザー媒質長で励起 光が吸収できるので，一体型レーザーの共振器長を短く することができる。共振器長を短くできれば，Qスイッ チパルスのパルス幅を短くでき，ピーク強度を向上する ことができる。そこで今回, Table 1 に示すNd濃度の異 なる3種類の大口径一体型Nd:YAG/Cr:YAGセラミック共 振器を製作し, 発振特性を比較した。 Nd濃度はそれぞ れ1.1，1.5，2.0at.\%で，Nd:YAGの厚みは励起光の吸収 率がほぼ同じになるように，それぞれ7，5，3.5 mmと した。一体化したCr:YAGセラミックはいずれも初期透 過率30\%で同じで, 厚みが約 3 mmである. Cr:YAGの端 面には出力鏡として反射率 $50 \%$ の誘電体コーティングを 行っている. Table 1の右端はLDからの励起光のワンパ ス吸収率の実測データで, 一体化していないNd:YAGセ ラミックを用いて測定した結果である。いずれも $95 \%$ 程 度の吸収が確認できた。一体型の場合Nd:YAGで吸収さ れなかった励起光はそのままCr:YAGに吸収され，光ス イッチ動作に不具合を起こす可能性があるが, 今回, 最 も薄いNd2.0at.\%でもワンパスで90\%以上の吸収が確認 できた．Fig. 3 に試作した 3 種類のセラミック共振器の外 観写真を示す。一体型共振器の外径は直径 $9 \mathrm{~mm}$ であ る。なお，セラミックスはすべて神島化学工業製であ る.

Fig. 4は3 種類の一体型共振器におけるレーザー光の入 出力特性を測定した結果である. 励起にはイエナオプ ティク製ファイバー出力型QCW LD (JOLD-120QPXF-2P 808 0.6iTEC)を用いた。 ファイバーのコア直径 は0.6 mm, NAは0.22. 励起波長 $808 \mathrm{~nm}$, 励起光のピー クエネルギーはLDの最大定格である $120 \mathrm{~W} ゙$ 一定とし， 横軸の励起エネルギーはパルス幅(時間)を変えて可変し た。最大のパルス幅は500 $\mu \mathrm{s}$, 繰り返しは20 Hzであ る. 励起光はレーザー媒質内でほぼコリメート状態で入 射し, 励起ビーム直径は $0.8 \mathrm{~mm} ゙$ あ。. 図より $\mathrm{A} \sim \mathrm{C} て ゙$ 受動Qスイッチ特有の発振パルスの数に比例する階段状 の出力特性が得られているが，階段の位置はずれている
ものの階段の高さ(パルスエネルギー)は, どの共振器で も $1.7 \mathrm{~mJ}$ でほぼ同じであることがわかる. Cr:YAGの初期 透過率はいずれも $30 \%$ で同じであるため，得られるパル スエネルギーが同じであることは各 $\mathrm{Nd}$ 濃度が異なって も誘導放出断面積は同じであることを示している。一方 でパルスの立ち上がり(しきい值)は1.1at.\%が11 mJで最 も低く、 Nd濃度が上がるほどしきい值は上昇し, $\mathrm{Nd}$ 1.5at.\%では12 mJ, Nd 2.0at.\%では15 mJ と大幅に上昇 している。これは高濃度のNd:YAGセラミックに於いて 報告されている蛍光量子効率の低下によるものと考えら れる ${ }^{9,10)}$. レーザー上準位に励起された $\mathrm{Nd}$ 原子のうち, 発光に寄与する原子の割合である蛍光量子効率は, Nd 1.1at.\%では0.8, Nd 2.0at.\%では，0.6まで低下すると 報告されている。このためNd 2.0at.\%では, 1.1at.\%に比 べ20\%程度，しきい值が上昇することが予測されるが， 今回の結果はこれを反映したものになっている.

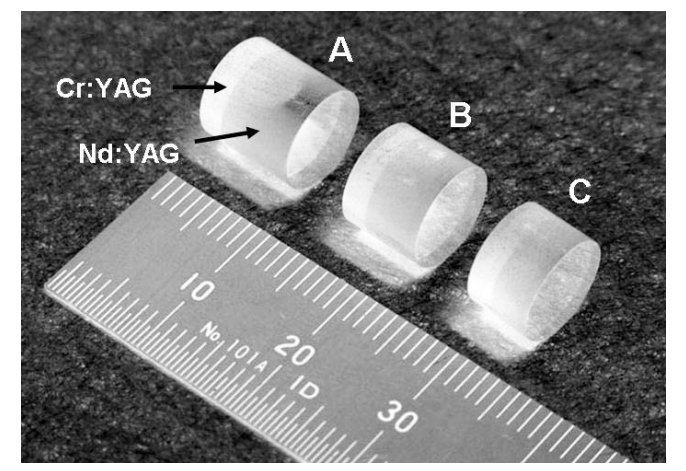

Fig. 3 Photograph of the composite Nd:YAG/Cr:YAG ceramic, monolithic laser cavities.

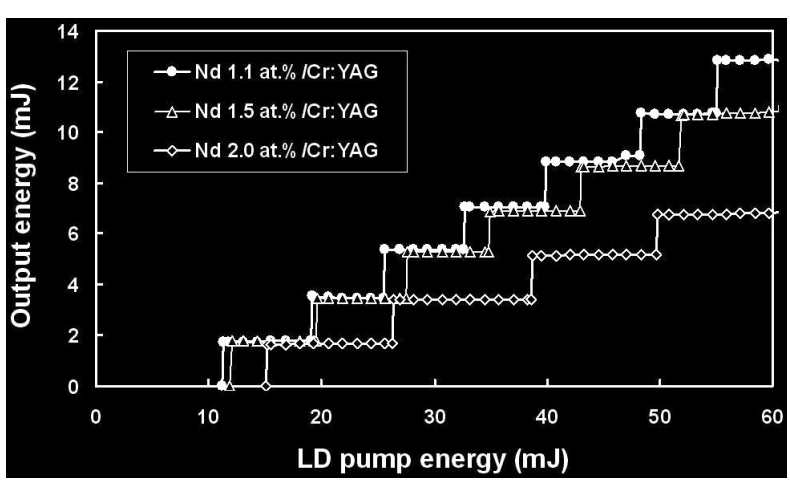

Fig. 4 Input pump energy versus laser output energy of passively Q-switched, composite ceramic lasers with different $\mathrm{Nd}$ concentration.

Table 1 Parameters of composite Nd:YAG/Cr:YAG ceramic laser cavities.

\begin{tabular}{cccccc}
\hline Nd:YAG & Cr:YAG & $\begin{array}{l}\text { Output } \\
\text { coupling }\end{array}$ & $\begin{array}{l}\text { Cavity } \\
\text { length }\end{array}$ & $\begin{array}{l}\text { Pump } \\
\text { absorption }\end{array}$ \\
\hline $\mathrm{A}$ & $\mathrm{Nd} 1.1 \mathrm{at} . \%, 7 \mathrm{mmt}$ & $\mathrm{T}=30 \%$ & $\mathrm{R}=50 \%$ & $9.5 \mathrm{~mm}$ & $95.1 \%$ \\
\hline $\mathrm{B}$ & Nd 1.5at.\%, 5mmt & $\mathrm{T}=30 \%$ & $\mathrm{R}=50 \%$ & $7.5 \mathrm{~mm}$ & $94.9 \%$ \\
\hline $\mathrm{C}$ & Nd 2.0at.\%, 3.5mmt & $\mathrm{T}=30 \%$ & $\mathrm{R}=50 \%$ & $5.9 \mathrm{~mm}$ & $93.5 \%$ \\
\hline
\end{tabular}


Fig. 5はA〜Cそれぞれの発振器からのパルス光の時間 幅を計測した結果で, 横軸を共振器長, 縦軸をパルス時 間幅で示した。受動Qスイッチレーザーのレート方程式 によるシミュレーション結果を実線で示す。この図のよ うにレーザー光のパルス幅はピコ秒のいわゆる「パルス ギャップ」領域で動作し共振器長が短くなるほど狭くな り, $6 \mathrm{~mm}$ と最も短い $\mathrm{Nd}$ 2.0at.\%の一体型共振器Cにおい て313 psが観測された。シミュレーション結果とも良く 一致している. Fig. 4の結果のように各共振器からのパ ルスエネルギーは同じであるため, パルスのピークパ ワーはパルス幅の短いNd 2.0at.\%で最大の5 MWが得ら れた。

さて，エンジンへの点火を考えた場合，エネルギーが 同じであればパルス幅が短く, ピークパワーの高い光の 方が，多光子吸収によるブレイクダウンが容易で有利で あるが，一方でしきい值が低く，エネルギー変換効率が 高いと言うことも実用上重要なポイントである。例えば Fig. 4の特性において, $18 \mathrm{~mJ}$ の入力励起エネルギーで1 パルスのみで点火するのであれば，ピークの高いCが最 も優れているが, 点火の確実性やより燃焼効率の改善が 可能な多パルス点火が実用的である ${ }^{11)}$ 。 その場合励起工 ネルギーを上げて，より多くのパルスを発生させた方が 有利である。例えばFig. 4において60 mJで励起した場 合, $\mathrm{Nd} 1.1 \mathrm{at} \%$ のAでは7パルス, 合計 $13 \mathrm{~mJ}$ の光エネル ギーが点火に投入できるが，Nd 1.5at.\%のBでは1パルス 少ない10.7 mJ, Nd 2.0at.\%のCではわずか4パルスの $6.7 \mathrm{~mJ}$ しか発生できない. 先ほど述べたようにAのパル ス幅は500 psとCより少し長いものの，3 MWはブレイク ダウンに十分なピーク強度であるため, エンジンに搭載 した場合，効率改善により有利である。加えて実際の自 動車エンジンに搭載した場合, レーザーの周囲温度は $100{ }^{\circ} \mathrm{C}$ 以上に上昇するため, レーザー発振しきい值が室 温での值より約 1.5 倍に上がることが, 我々のこれまで の研究で判明している ${ }^{12)}$. その場合, 室温でのしきい值 が高いCは高温でよりパルス数と出力エネルギーが減少 するため，さらに不利である。そこで本実験結果から， 3種類のNd濃度の共振器を比較してNd 1.1at.\%のAがエン ジン点火用として現状, 最も適していると判断した。 以 下では主にこの共振器を用いて多点点火レーザーの開発 を進めた。

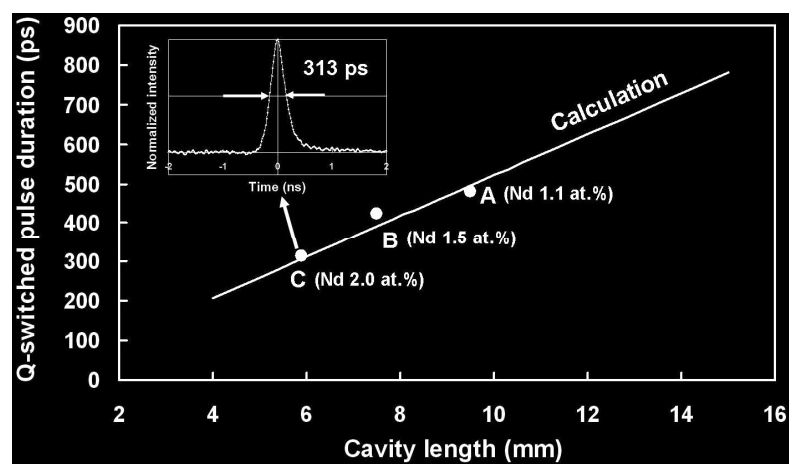

Fig. 5 Q-switched pulse durations of composite ceramic lasers as a function of cavity length.
なお，点火に必要な点火系の全エネルギー消費量を レーザー点火とスパークプラグによる火花点火とを比べ た場合，プラグは電気効率約35\%で，1点火当たり $35 \mathrm{~mJ}$ 程度の放電エネルギーを出力すると言われており，従っ て約100 mJの電気エネルギーを消費する。これに対して レーザーの場合, 光 - 光変換効率は $20 \%, \mathrm{LD}$ の電気 光変換効率は50\%程度であるので全体のエネルギー効率 は10\%程度とプラグよりかなり低い. しかし，燃焼条件 により $2 \mathrm{~mJ}$ の光出力から点火が可能であるので，1点火 当たり必要なエネルギー消費量としては，プラグと遜色 がない，ただし，LDの温度調節機構などが付帯的に必 要になる場合には，レーザーの方がエネルギー消費量が 格段に大きくなる。従って今後は実用化に際し，レー ザー点火系全体のエネルギー効率改善が一つの重要な テーマである．同時多点点火を採用する場合には，なお さら改善が必要になるであろう。

\section{3 各レーザーの特性の均一性}

今回の構成では同一の共振器の異なる領域を用いて複 数のレーザー光を発振させる。 その際, それぞれのレー ザー特性，しきい值，パルスエネルギーなどが揃ってい ることが望ましい，先ほども述べたように，レーザー媒 質，光スイッチ媒質にYAGセラミックを用いた一つの 理由は, セラミックが大面積でも Nd添加濃度が均一で, 脈理等がなく均質であると報告されているためである が, 今回試作した大口径一体型共振器でそれを実験的に 評価した。

Fig. 6, Fig. 7はそれぞれNd1.1at.\%のNd:YAG/Cr:YAG セラミック一体型共振器Aを端面励起し, 励起位置を $\phi 9 \mathrm{~mm}$ の口径内で $0.5 \mathrm{~mm}$ 刻みで全面走査したときに出力 面から得られた最初の1パルスのレーザー出力の面内分 布と, 中心部分 $\phi 5 \mathrm{~mm}$ 面内のヒストグラムを示す。励起 ビーム径は $\phi 0.8 \mathrm{~mm} ゙$ る。平均で $1.6 \mathrm{~mJ}$, 標準偏差 $0.025 \mathrm{~mJ}$, 面内のばらつきは土 $0.1 \mathrm{~mJ}$ 未満に収まってお り，多点点火用として実用的に問題のない良好な面内均 一性が確認できた。特にこの出力のばらつきは, Nd:YAGセラミックだけでなく，一体化したCr:YAGセラ

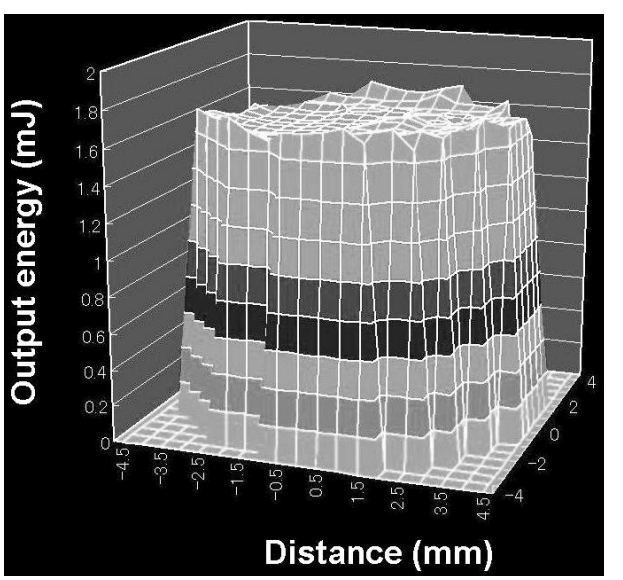

Fig. 6 Distribution of Q-switched output energy in the Nd:YAG/Cr:YAG ceramic laser with Nd:1.1at.\%. 


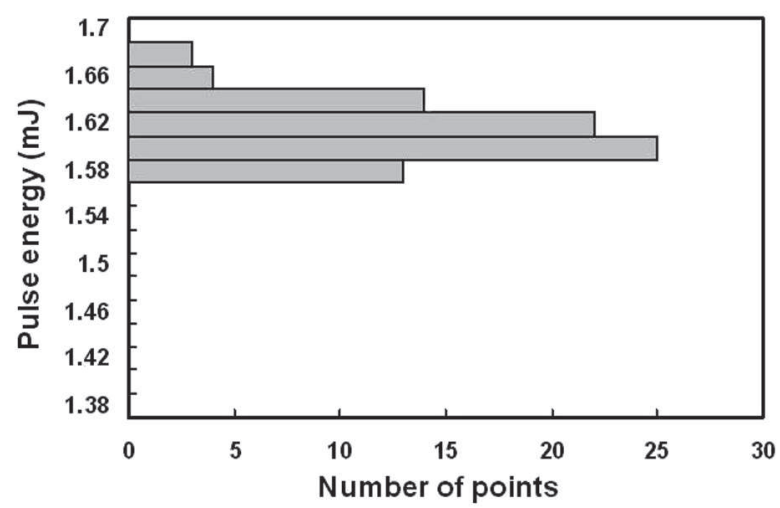

Fig. 7 Histogram of the output energy.

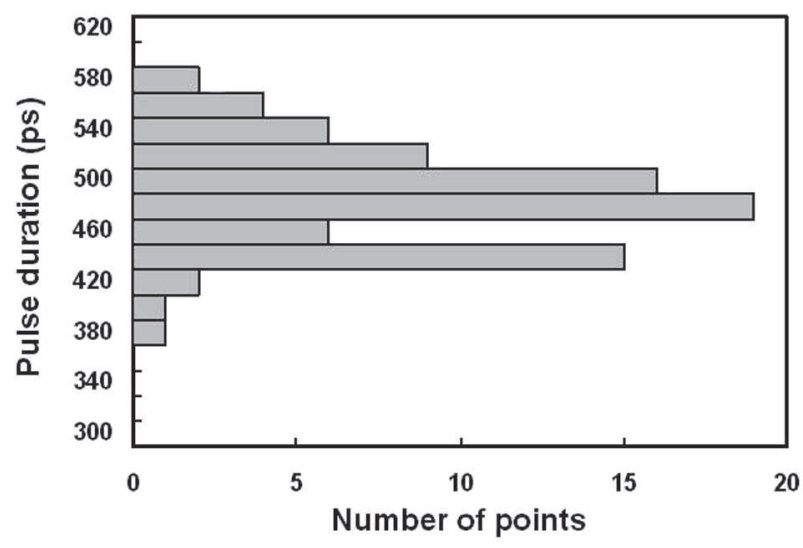

Fig. 8 Histogram of the pulse duration.

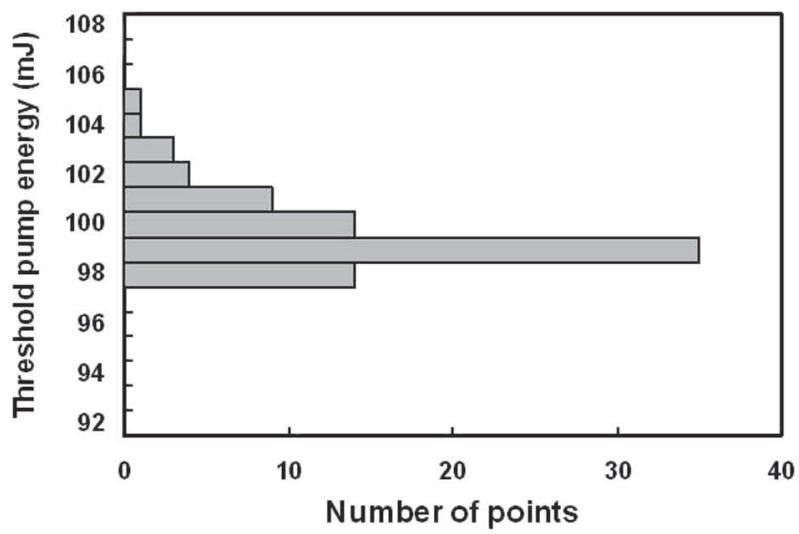

Fig. 9 Histogram of the threshold pump energy.

ミックやその接合界面の品質の均一性を含んでおり, 改 めてYAGセラミックの均一性の高さを確認できた。さ らにFig. 8, Fig. 9はそれぞれ同じくパルス幅, パルスを 発振するしきい值のばらつきを測定したヒストグラムで

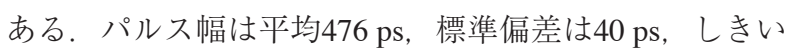
值は99 mJ, 標準偏差 $1.5 \mathrm{~mJ}$ 同様にばらつきは小さ い。この結果より面内の, どの3力所を励起してもほほ 同じ特性が得られることが予測される。

3.4 小型同時3点点火レーザーモジュールの製作

Fig. 10右は今回試作した同時3点点火可能な超小型モ
ジュールであり，左のM14ロングリーチ点火プラグに対 し, 最外径は $\phi 19 \mathrm{~mm}$ で同一, 長さは78 mmと逆に少し 短くすることができた。励起並びにブレイクダウンのレ ンズ光学系の設計は基本的に先の1点点火レーザーと同 一で，レンズの口径だけを小さく加工して組み込んだ。 モジュール中央には, 先の外径 $\phi 9 \mathrm{~mm}$, 長さ $9.5 \mathrm{~mm}$ の Nd1.1at.\%のNd:YAG/Cr:YAGセラミック一体型共振器A を搭載し，図のように一方より3本の光ファイバーとそ れぞれ個別の励起光学系を用いて異なる3力所を端面励 起し，発生したレーザーパルスを同様に個別のレンズで 1旦ビーム径を拡大した後，それぞれプリズムによりモ ジュールの中心軸に対して光路に角度を加え，互いの ビームが少し外に広がるようにした後, 最後にレンズで 集光している，図のように3点で安定した大気中ブレイ クダウンが観測できた。集光点とレンズとの距離は $10 \mathrm{~mm}$ ，かつ各集光点の距離も約 $10 \mathrm{~mm}$ あ゙る. 3つの 独立したレーザーを近接させた構成ではあるが，レー ザー共振器が一体で, 且つ3つのレーザーで共通である ため, モジュール内部のレンズの取り付け位置を機械精 度の範囲で加工することで, 組み立て後, 光軸のアライ メントの調整の必要なく, モジュールをプラグサイズま で小型にすることができた。

Fig. 11は試作したモジュールにおける3点点火各レー ザーの入出力特性を示す。ただし一体型共振器からの出 力を直接測定した結果である。励起はLDの波長のばら

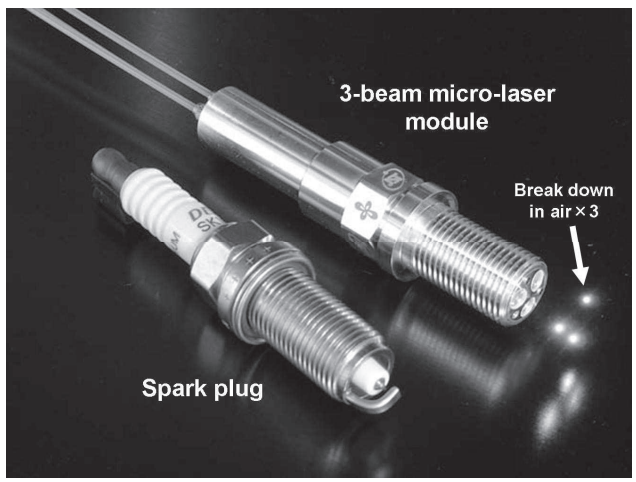

Fig. 10 Photograph of oscillating actual plug-sized three beam laser.

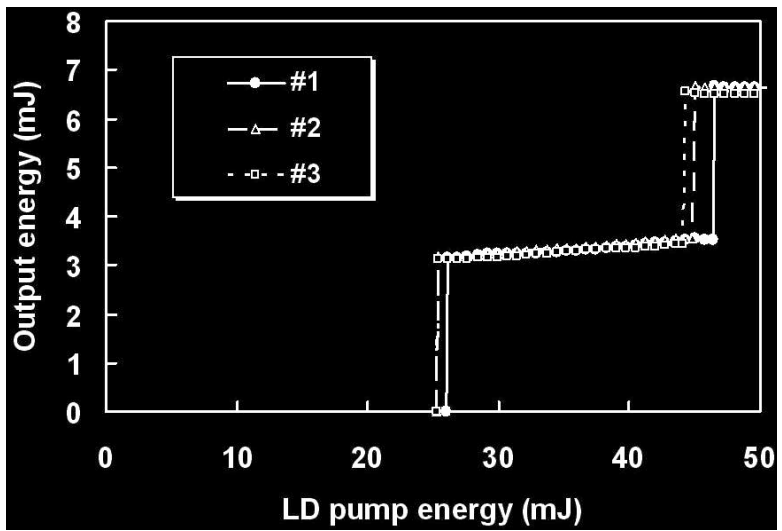

Fig. 11 Input-output characteristics of each laser. 
つきの影響を考慮し, 同じLDからのファイバーを3カ所 に差し替えながら測定した。発振しきい值, パルスエネ ルギーともほとんど重なるほどの均一性の高さを示して いる。 このモジュールでは励起ビーム径をこれまでの単 結晶での点火実験と同様, $\phi 1.1 \mathrm{~mm}$ まで拡大している。 これによりパルスエネルギーは $3.2 \mathrm{~mJ}$ まで上昇，パルス 幅は500 psで変わらないため, ピークエネルギーは $6 \mathrm{MW}$ 以上なった。この值は既に報告している単結晶 のNd:YAG/Cr:YAGレーザーと同等であり，YAGセラ ミックにおいても単結晶と同等の高出力レーザー発振特 性が得られることが分かった，点火にはレーザー光の偏 光方向は関係ないため, 媒質はセラミックでまったく支 障がなく，量産性やストレスに対する耐力も高いことか ら，エンジン点火には理想的なレーザー材料であるとい える.

なお3点それぞれ別々のLDで励起を行った場合，一般 には各LDの波長が異なり $\mathrm{Nd}: \mathrm{YAG}$ への吸収係数が変化 し, その結果, 同じ励起エネルギーでも各ビームの発振 しきい值及び発振のタイミングにずれが生じる。実際に 測定したところ，同じ励起エネルギーの場合各ビーム間 最大で $30 \mu \mathrm{s}$ のずれが観測された。点火夕イミングのず れとして許される時間は, エンジンのクランク角換算で 最大 $1{ }^{\circ}$ の時間と言われている。例えば $6000 \mathrm{rpm}$ のエンジ ン回転数においては, 1秒当たり 100 回転なので1回転当 たり $10 \mathrm{~ms}$ ，これを360で割ってクランク角 1 ○では $28 \mu \mathrm{s}$ と見積もられる。従って今回測定されたずれは，ほぼ許 容される最大であった。ささに, 各LDの電流值(ピーク エネルギー)を5\%以下の範囲で調整すれば，3点の発振 タイミングを完全に一致させることが可能である た逆に，それぞれのビームの発振タイミングを意眓的に 大きくずらすことも可能である.

\section{4. まとめ}

今回エンジン点火用レーザーの高性能化を目指し, 同 時3点点火レーザーの試作研究を行った。レーザーの構 成として信頼性上問題の少ない3つのレーザーをアレイ 状に近接する構成とし, アライメントのやりやすさ, 均
一性の高さから, Nd:YAG/Cr:YAGセラミック一体型共 振器を適用し特性を評価した。その結果Nd1.1at.\%の共 振器を選択し，小型モジュールを試作した。3点点火で ありながら現行のプラグと同サイズまで小型化に成功 し, 各レーザー光からエネルギー $3.2 \mathrm{~mJ}$, ピーク強度 $6 \mathrm{MW}$ 超える高輝度光パルスを得ることに成功した。 今後今回試作した多点点火レーザーによるエンジン燃焼 効率の改善の検証を行う予定である.

\section{謝 辞}

本報告は科学技術振興機構, JST産学官共同シーズイ ノベーション事業 育成ステージの研究成果の一部であ り，研究の円滑な遂行に尽力いただいたJST並びに共同 研究企業である日本自動車部品総合研究所, デンソー関 係各位に感謝する。またレーザーモジュールの機構設計 を行って頂いた自然科学研究機構 分子科学研究所, 装 置開発グループの水谷信雄係長に感謝する.

\section{参考文献}

1）常包 正樹, 猪原 孝之, 安藤彰浩, 木戸 直樹, 金原 賢治, 平等 拓範：レーザー研究 37 (2009) 283.

2) R. Hickling and W. R. Smith: SAE Paper 740114 (1974) 555.

3) J. D. Dale, M. D. Checkel, and P. R. Smy: Prog. Energy Combust. Sci. 23 (1997) 379.

4) T. X. Phuoc: Combustion and Frame 122 (2000) 508.

5) M. H. Morsy, Y. S. Ko, S. H. Chung, and P. Cho: Combustion and Frame 125 (2001) 724.

6) N. Pavel, M. Tsunekane and T. Taira: Opt. Express 19 (2011) 9378.

7) G. A. Kuma, J. Lu, A. A. Kaminskii, K. Ueda, H. Yagi, T. Yanagitani, and N. V. Unnikrishnan: IEEE J. Quantum Electron. 40 (2004) 747.

8) T. Taira: IEEE J. Sel. Top. Quantum Electron. 13 (2007) 798.

9) V. Lupei, T. Taira, A. Lupei, N. Pavel, I. Shoji, and A. Ikesue: Opt. Commun. 195 (2001) 225.

10) A. Benayas, D. Jaque, C. Jacinto, and A. A. Kaminskii: IEEE J. Quantum Electron. 46 (2010) 1870.

11) M. Tsunekane, T. Inohara, A. Ando, N. Kido, K. Kanehara, and T. Taira: IEEE J. Quantum Electron. 46 (2010) 277.

12) M. Tsunekane and T. Taira: CLEO/Europe 2009, CA. (2009) p. 30. 